\title{
Analisis Struktur Modal dan Kebijakan Dividen Dalam Mengukur Nilai Perusahaan Pada PT. Nippon Indosari Corporindo Tbk
}

\author{
Edison Hamid \\ Sekolah Tinggi Ilmu Ekonomi Tribuana \\ edisonvgh@yahoo.com
}

\begin{abstract}
Abstrac
This study aims to determine how the Capital Structure and Dividend Policy in Measuring Firm Value. The research object, namely PT. Nippon Indosari Corporindo Tbk, which is taken from the financial statements for the period 2015-2019. This study used a qualitative method consisting of three variables, namely capital structure and dividend policy as independent variables and firm value as the dependent variable. Methods of data analysis used in this study is an analysis of capital structure and dividend policy in measuring usevalues of the company. The test results show that the average capital structure calculated using a debt to equity ratio of $78 \%$ per year as a whole is categorized as very good, when viewed from the general standard or the industry average of less than 1 time. For the average dividend policy calculated using the dividend payout ratio of 26\%, it shows that the dividend payout ratio is included in very good criteria because it has reached company standards. Then from the results of the comparison of capital structure, dividend policy and company value for the last 5 years of the 2015-2019 period, the weight value of capital structure, dividend policy in measuring company value is $78 \%$ and $26 \%$.
\end{abstract}

Keywords: Capital Structure, Dividend Policy, Company Value

\begin{abstract}
Abstrak
Penelitian ini bertujuan untuk mengetahui bagaimana Struktur Modal dan Kebijakan Dividen dalam Mengukur Nilai Perusahaan. Objek penelitian yaitu PT. Nippon Indosari Corporindo Tbk, yang diambil dari laporan keuangan periode 2015-2019. Penelitian ini menggunakan metode kualitatif yang terdiri dari tiga variabel yaitu struktur modal dan kebijakan dividen sebagai variabel bebas dan nilai perusahaan sebagai variabel terikat. Metode analisis data yang digunakan dalam penelitian ini adalah analisis struktur modal dan kebijakan dividen dalam mengukur nilai guna perusahaan. Hasil pengujian menunjukkan bahwa rata-rata struktur modal yang dihitung dengan menggunakan debt to equity ratio sebesar $78 \%$ per tahun secara keseluruhan dikategorikan sangat baik, jika dilihat dari standar umum atau rata-rata industri kurang dari 1 kali. Untuk rata-rata kebijakan dividen yang dihitung dengan menggunakan dividend payout ratio sebesar $26 \%$ menunjukkan bahwa dividend payout ratio termasuk dalam kriteria sangat baik karena telah mencapai standar perusahaan. Kemudian dari hasil perbandingan struktur modal, kebijakan dividen dan nilai perusahaan selama 5 tahun terakhir periode 2015-2019, bobot nilai struktur modal, kebijakan dividen dalam mengukur nilai perusahaan adalah $78 \%$ dan $26 \%$.
\end{abstract}

Kata Kunci : Struktur Modal, Kebijakan Dividen, Nilai Perusahaan

\section{PENDAHULUAN}

Dalam meningkatkan kesejahteraan pemegang sahamnya, perusahaan tidak hanya ingin memperoleh laba yang tinggi saja, melainkan ingin dapat meningkatkan nilai perusahaannya. Menurut Harmono (2014:1), meningkatkan nilai perusahaan merupakan ukuran nilai objektif oleh publik dan orientasi pada kelangsungan hidup perusahaan.

Menurut Manopo dan Arie (2016:486), pentingnya nilai perusahaan membuat investor dan kreditor semakin selektif dalam berinvestasi maupun 
memberikan kredit kepada perusahaan. Nilai perusahaan akan memberikan sinyal positif dimata investor untuk menanamkan modal pada sebuah perusahaan, sedangkan bagi pihak kreditur nilai perusahaan mencerminkan kemampuan perusahaan untuk membayar utangnya sehingga pihak kreditur tidak merasa khawatir dalam memberikan pinjaman kepada perusahaan tersebut.

Menurut Sudana (2011:6), keputusan pendanaan yang tepat dapat dilakukan dengan memilih sumber dana yang dipakai untuk membelanjai investasi yang direncanakan dengan berbagai alternatif sumber dana yang tersedia, sehingga diperoleh suatu kombinasi pembelanjaan yang paling efisien.

Perusahaan akan selalu memikirkan pekerjaan yang efektif dan efisien agar mudah dikontrol dan dinilai (Marpaung, 2022). Perusahaan harus mempertimbangkan kelebihan dan kekurangan masing-masing sumber modal dalam melakukan keputusan pendanaan agar tercipta keputusan yang tepat. Dalam mengambil keputusan pendanaan yang tepat, perusahaan dapat menggunakan konsep struktur modal.

Struktur modal adalah perbandingan dalam mentukan kebutuhan belanja, yang berasal dari antara modal asing yang diperoleh dari utang jangka panjang dan utang jangka pendek dan modal sendiri dari penerbitan saham di pasar bursa efek (Indonesia Stock Exchange). Yang menjadi persoalan dalam menggunakan struktur modal adalah bagaimana perusahaan dapat memadukan komposisi dana permanen yang digunakannya dengan mencari paduan dana yang dapat meminimumkan biaya modal perusahaan agar dapat memaksimalkan nilai peusahaan. Menurut Ali Rodoni (2014:130) hal ini lah yang menjadi tujuan akhir dari struktur modal, yakni membuat komposisi sumber pembiayaan yang paling optimal.

Menurut Harmono (2017:112) indikator yang umum digunakan untuk menentukan komponen struktur modal yaitu :

a. DER (Debt to Equity Ratio)

b. DAR (Debt to Assets Ratio)

c. Long Term Debt to Equity

Dalam penelitian ini alat ukur yang digunakan untuk mengukur struktur modal adalah DER (Debt to Equity Ratio).

Keputusan atau kebijakan lain yang harus dibuat perusahaan adalah kebijakan dividen. Kebijakan dividen adalah satu satunya peran manajer keuangan yang terkait langsung dengan para pemegang saham dengan membayarkan keuntungan perusahaan langsung kepada para pemegang saham.

Dalam kebijakan dividen terdapat trade off dan merupakan pilihan yang tidak 
mudah antara membagikan laba sebagai dividen atau diinvestasikan kembali. Apabila perusahaan memilih membagikan laba sebagai dividen maka tingkat pertumbuhan akan berkurang dan berdampak negatif terhadap saham. Disisi lain, apabila perusahaan tidak membagikan dividen maka pasar akan memberikan sinyal negatif kepada prospek perusahaan. Peningkatan dividen memberikan sinyal perubahan yang menguntungkan pada harapan manajer dan penurunan dividen menunjukkan pandangan pesimis prospek perusahaan dimasa yang akan datang (Marpaung, 2021a)

Menurut Harmono (2014:138) Dividen Payout Ratio (DPR) dapat merefleksikan tarif keuntungan pasar yang menyamakan nilai sekarang prediksi dividen yang akan datang dengan nilai sekarang harga pasar saham.

Dividen Payout Ratio $=\frac{\text { Dividen }}{\text { Laba Bersih }}$

Pada umumnya pembayaran dividen dalam bentuk dividen tunai (cash dividend). Cara lain untuk pembayaran dividen adalah dalam bentuk saham yang biasa disebut stock dividend. Bagi perusahaan publik, pembagian dividen dilakukan secara teratur setiap reguler baik triwulan, semesteran, atau tahunan.

Struktur modal dan kebijakan dividen dalam mengukur nilai perusahaan
Struktur modal merupakan proporsi pendanaan perusahaan baik dengan menggunakan sumber dana internal maupun sumber dana eksternal (hutang). Jika pendanaan internal tidak mencukupi, maka manajemen akan memutuskan untuk menggunakan hutang. Pecking order theory menjelaskan bahwa modal yang berasal dari internal lebih disukai perusahaan, karena rendahnya risiko yang akan ditanggung perusahaan karena minimnya hutang yang digunakan.

Tingginya minat investor akan menentukan kebijakan dividen yang dibuat oleh perusahaan dalam rangka menjamin kesejahteraan para pemegang sahamnya. Kebijakan dividen (dividend policy) merupakan keputusan seberapa besar laba yang diperoleh perusahaan pada akhir tahun akan dibagi kepada pemegang saham sebagai dividen kas atau disimpan dalam bentuk laba ditahan sebagai sumber pendanaan perusahaan. Rasio pembayaran dividen (dividend payout ratio) akan menunjukkan persentase laba perusahaan yang dibagi kepada pemegang saham biasa dalam bentuk dividen kas.

Menurut Harmono (2014:12), dengan adanya struktur modal yang baik dan kebijakan dividen yang dibagikan kepada para pemegang saham, ini dapat digunakan dalam mengukur nilai perusahaan. 
Penelitian terdahulu yang dilakukan oleh Umi, Gatot, dan Ria (Universitas Negeri Jakarta), Pengaruh Kebijakan Dividen, Kebijakan Hutang, dan Profitabilitas terhadap Nilai Perusahaan adapun hasil penelitiannya adalah Kebijkan Dividen, Kebijakan Hutang berpengaruh positif tetapi tidak signifikan terhadap Nilai Perusahaan dan Profitabilitas berpengaruh positif signifikan.

Berdasarkan uraian diatas dan penelitian terdahulu maka hipotesis dalam penelitian ini adalah "Diduga struktur modal dan kebijakan dividen dapat mengukur nilai perusahaan"

\section{METODE PENELITIAN}

Menurut Sugiyono (2013:12) menyatakan bahwa "Metode penelitian naturalistik/kualitatif, digunakan untuk meneliti pada tempat yang alamiah, dan penelitian tidak membuat perlakuan, karena peneliti dalam mengumpulkan data bersifat emic, yaitu berdasarkan pandangan dari sumber data, bukan pandangan peneliti.

Untuk metode penelitian yang digunakan dalam penelitian ini adalah Penelitian kualitatif untuk mengembangkan teori, dan memastikan kebenaran apa yang sudah dianalisis, dan meneliti sejarah perkembangan.
Sumber data yang digunakan dalam penelitian ini adalah data sekunder. Data sekunder dalam penelitian ini diperoleh melalui laporan keuangan perusahaan yang telah dipublikasikan dan yang telah diaudit, dapat diperoleh melalui situs www.idx.co.id.

Jenis data yang digunakan dalam penelitian ini adalah data kuantitatif. Yaitu menggunakan data angka berupa laporan keuangan perusahaan PT Nippon Indosari Corpindo Tbk yang telah diaudit dan dipublikasikan di Bursa Efek Indonesia (BEI) periode 31 Desember 2015 sampai dengan 2019, meliputi neraca, laporan laba-rugi dan laporan posisi keuangan.

Dan dalam suatu penelitian diperlukan adanya suatu data sebagai hasil akhir dari penelitian. Untuk pengumpulan data yang konkrit peneliti melaksanakan beberapa teknik pengumpulan data, teknik pengumpulan studi kepustakaan dan dokumentasi.

\section{Metode Analisis Data}

Metode analisa data yang dipakai dalam penelitian ini adalah motode deskriptif kualitatif yaitu menjelaskan hasil penelitian yang berupa data-data laporan keuangan yang berhubungan dengan nilai perusahaan, struktur modal dan kebijakan dividen (Marpaung, 2021b)

Menurut Wibowo (2011:43) motode penelitian deskriptif kualitatif adalah penggambaran secara kualitatif fakta, data, 
atau objek material yang bukan berupa angka, melainkan berupa ungkapan bahasa atau wacana (apapun itu bentuknya) melalui interprestasi yang tepat dan sistematis.

Peneliti mengumpulkan data yang sesuai dengan keadaan yang sebenarnya, menyajikan dan menganalisisnya sehingga dapat memberikan perbandingan yang cukup jelas mengenai objek yang diteliti yang kemudian dapat ditarik suatu kesimpulan dan data tersebut dianalisis dengan menggunakan analisis rasio.

Untuk menganalisis data dalam penelitian ini, peneliti meggunakan rumus rasio keuangan sebagai berikut:

1. Nilai Perusahaan

Langkah-langkah yang akan dilakukan dalam melakukan analisis data meliputi :

a. Mengidentifikasi aktivitas

b. Mengukur sejauh mana kemampuan perusahaan memenuhi kewajiban jangka panjang nya

c. Mengukur berapa besar bagian laba bersih setelah pajak yang dibayarkan sebagai dividen kepada pemegang saham

d. Menghitung bobot, yaitu dengan cara mengalikan nilai pencapaian target

e. Dengan bobot penliaian setiap indikator dengan bobot penilaian setiap indikator berdasarkan hasil dari struktur modal dan dividen payout ratio lalu dibandingkan dengan rata-rata industri

1. Struktur Modal

$$
\text { Debt to Equity Ratio }=\frac{\text { Total Hutang }}{\text { Total Modal }}
$$

(Kasmir, 2010:112)

Menurut kasmir (2016:159), Secara umum rasio struktur modal kerja bisa dikatakan baik jika mencapai standar umum rata rata yaitu $0-90 \%$. Dilihat dari tabel 2.1 berikut ini :

Tabel 2.1

Standar Rasio Industri DER

\begin{tabular}{|c|c|}
\hline Standar Industri & Kriteria \\
\hline$\geq 90 \%$ & Kurang Baik \\
\hline
\end{tabular}

2. Kebijakan Dividen

Pengembalian atas Ekuitas (Return on Equity)

$$
\text { Dividen Payout Ratio }=\frac{\text { Dividen }}{\text { Laba Bersih }}
$$

Menurut Martono dan Agus (2010:253), Besaran dividen payout ratio pada rasio industri pada umumnya berkisar antara $25 \%-50 \%$ :

Tabel 2.2

Standar Rasio Industri Deviden Payout

\begin{tabular}{|c|c|}
\hline Standar Industri & Kriteria \\
\hline$\geq 60 \%$ & Buruk \\
\hline $50-60 \%$ & Kurang Baik \\
\hline $25-50 \%$ & Sangat Baik \\
\hline $15-25 \%$ & Cukup Baik \\
\hline $10-15 \%$ & Baik \\
\hline
\end{tabular}




\section{Deskripsi Operasional Variabel}

Definisi operasional variabel penelitian menurut Sugiyono (2015:38) adalah suatu atribut atau sifat atau nilai dari objek atau kegiatan yang memiliki variasi tertentu yang telah ditetapkan oleh peneliti untuk dipelajari dan kemudian ditarik kesimpulannya. Definisi variabelvariabel penelitian harus dirumuskan untuk menghindari kesesatan dalam mengumpulkan data. Dalam penelitian ini ada 3 variabel yaitu:

a) Variabel Dependen (Y) yaitu Nilai Perusahaan (Value of the firm), nilai perusahaan dalam penelitian ini diproksikan dengan penggunaan struktur modal, yang dihitung menggunakan debt to equity ratio dan kebijakan dividen yang dihitung menggunakan dividen payout ratio.

b) Variabel Independen (X1) yaitu Struktur Modal, struktur modal merupakan gambaran dari bentuk proporsi finansial perusahaan yaitu antara modal yang dimiliki yang bersumber dari utang dan modal yang menjadi sumber pembiayaan suatu perusahaan.

c) Variabel Independen (X2) Kebijakan Deviden, kebijakan dividen dalam penelitian dikonfirmasikan dalam bentuk Dividen Pay out Ratio (DPR). Menurut Harmono (2014:138) Dividen Payout Ratio (DPR) dapat merefleksikan tarif keuntungan pasar yang menyamakan nilai sekarang prediksi dividen yang akan datang dengan nilai sekarang harga pasar saham

\section{HASIL DAN PEMBAHASAN}

Analisis Debt to Equity Ratio Pada PT. Nippon Indosari Corporindo Tbk

Debt to Equity Ratio merupakan rasio digunakan untuk mengukur seberapa besar perusahaan dibelanjai oleh pihak kreditur. Semakin rendah rasio maka semakin baik perusaaan dalam menggunakan sumber modalnya yang artinya perusahaan dapat menciptakan nilai peusahaan yang baik dimasa mendatang. Rasio Debt to Equity Ratio yang bagus adalah yang mengalami penurunan setiap tahunnya, karena ini artinya perusahaan dapat memaksimalkan jumlah modal untuk menjamin setiap hutangnya. Berdasarkan laporan posisi keuangan konsolidasian PT. Nippon Indosari Corporindo Tbk periode 2015 - 2019 dalam milyaran rupiah, maka Debt to Equity Ratio dan standar industri adalah seperti dalam tabel 3.1 dibawah ini:

Tabel 3.1

Debt to Equity Ratio

\begin{tabular}{|l|c|c|c|c|}
\hline Tahun & $\begin{array}{c}\text { Total } \\
\text { Hutang } \\
(\mathbf{a})\end{array}$ & $\begin{array}{c}\text { Total } \\
\text { Modal } \\
(\mathbf{b})\end{array}$ & $\begin{array}{c}\text { DER } \\
(\mathbf{c =} \mathbf{a} / \mathbf{b})\end{array}$ & Kriteria \\
\hline 2015 & 1.517 & 1.188 & $127 \%$ & Kurang Baik \\
\hline 2016 & 1.476 & 1.441 & $102 \%$ & Kurang Baik \\
\hline 2017 & 1.739 & 2.820 & $61 \%$ & Sangat Baik \\
\hline 2018 & 1.476 & 2.916 & $50 \%$ & Sangat Baik \\
\hline 2019 & 1.589 & 3.092. & $51 \%$ & Sangat Baik \\
\hline
\end{tabular}


Sumber: Laporan Keuangan PT. Nippon Indosari Corporindo Tbk

Berdasarkan hasil perhitungan diatas dapat diketahui bahwa Debt to Equity Ratio pada tahun 2015 sampai dengan tahun 2019 mengalami fluktuatif. Tetapi masih dalam batas wajar dan berdasarakan standar industri masuk dalam katagori sangat baik.

\section{Analisis Dividen Payout Ratio pada PT.}

\section{Nippon Indosari Corporindo Tbk}

Dividen payout ratio (DPR) yaitu, rasio ini mengukur berapa besar bagian laba bersih setelah pajak yang dibayarkan sebagai dividen kepada pemegang saham. Semakin besar rasio ini berarti semakin sedikit bagian laba yang ditahan untuk membelanjai investasi yang dilakukan perusahaan. Berdasarkan laporan posisi keuangan konsolidasian PT. Nippon Indosari Corporindo Tbk periode 2015 2019 dalam jutaan rupiah, maka Dividen Payout Ratio dan standar industri adalah seperti dalam tabel 3.2 dibawah ini:

Tabel 3.2 Dividen Payout Ratio

\begin{tabular}{|c|c|c|c|c|}
\hline Tahun & $\begin{array}{c}\text { Dividen } \\
\text { Kas } \\
(\mathbf{a})\end{array}$ & $\begin{array}{c}\text { Laba } \\
\text { Tahun } \\
\text { Bersih } \\
(\mathbf{b})\end{array}$ & $\boldsymbol{D P R}$ & Kriteria \\
$(\mathbf{c = a} / \mathbf{b})$ & \\
\hline 2015 & 27.991 & 270.538 & $10 \%$ & Baik \\
\hline 2016 & 53.698 & 279.777 & $19 \%$ & Cukup Baik \\
\hline 2017 & 69.488 & 135.364 & $51 \%$ & Kurang Baik \\
\hline 2018 & 36.005 & 127.171 & $28 \%$ & Sangat Baik \\
\hline 2019 & 59.724 & 236.518 & $25 \%$ & Sangat Baik \\
\hline
\end{tabular}

Sumber: Laporan Keuangan PT. Nippon Indosari Corporindo Tbk
Berdasarkan hasil perhitungan diatas dapat diketahui bahwa Dividen Payout Ratio pada tahun 2015 sampai dengan tahun 2019 mengalami fluktuatif. Tetapi masih dalam batas wajar dan berdasarakan standar industri masuk dalam katagori baik Analisis debt to equity ratio dan dividen payout ratio dalam mengukur nilai perusahaan.

Struktur modal baik di dapatkan dari proporsi penggunaan pendanaan perusahaan maupun dengan menggunakan sumber dana internal dan sumber dana eksternal (hutang). Penggunaan hutang akan menghasilkan keuntungan bagi perusahaan apabila biaya yang dikeluarkan untuk penggunaan hutang lebih kecil dibandingkan biaya penggunaan modal sendiri. Hal tersebut dapat menciptakan nilai perusahaan.

Begitupun kebijakan dividen yang dibuat oleh perusahaan, dividen harus dibagikan sesuai laba bersih yang didapatkan perusahaan, jika persentase laba yang diberikan kepada pemegang saham dalam bentuk dividen begitu besar maka semakin sedikit bagian laba yang ditahan untuk membelanjai investasi yang dilakukan perusahaan maka akan berakibat pada buruknya nilai perusahaan dimasa yang akan datang, untuk hasil perhitungan debt to equity ratio dan dividen payout ratio terlihat pada tabel 3.3 
Tabel 3.3

DER dan DPR

\begin{tabular}{|c|c|c|}
\hline Tahun & $\begin{array}{c}\text { DER } \\
(\mathbf{X 1})\end{array}$ & $\begin{array}{c}\text { DPR } \\
(\mathbf{X} 2)\end{array}$ \\
\hline 2015 & $127 \%$ & $10 \%$ \\
\hline 2016 & $102 \%$ & $19 \%$ \\
\hline 2017 & $61 \%$ & $51 \%$ \\
\hline 2018 & $50 \%$ & $28 \%$ \\
\hline 2019 & 51 Kali & $25 \%$ \\
\hline Rata-rata & $\mathbf{7 2 \%}$ & $\mathbf{2 6 \%}$ \\
\hline Kriteria & Sangat Baik & Sangat Baik \\
\hline
\end{tabular}

Sumber: Laporan Keuangan PT. Nippon

Indosari Corporindo Tbk

Berdasarkan tabel 3.3 PT. Nippon Indosari Corporindo Tbk, dimana rata-rata debt to equity ratio (DER) berada pada kriteria sangat baik yaitu 0.72 kali begitu juga halnya dividen payout ratio (DPR) juga berada pada katagori sangat baik yaitu 26\%. Hal ini dapat dikatagorikan bahwa nilai perusahaan sangat baik berdasarkan rata-rata standar industri.

\section{Hasil Pembahasan}

Dari hasil analisis diatas dapat disimpulkan bahwa penurunan Total Debt to Equity Ratio menunjukkan nilai perusahaan yang baik karena perusahaan tidak menanggung resiko finansial yang besar dari hutang/kewajiban setiap tahunnya dikarenakan adanya modal yang lebih besar, berikut grafik perkembangan deb to equity ratio seperti pada gambar 3.1:
Gambar 3.1

Grafik Debt to Equity Ratio

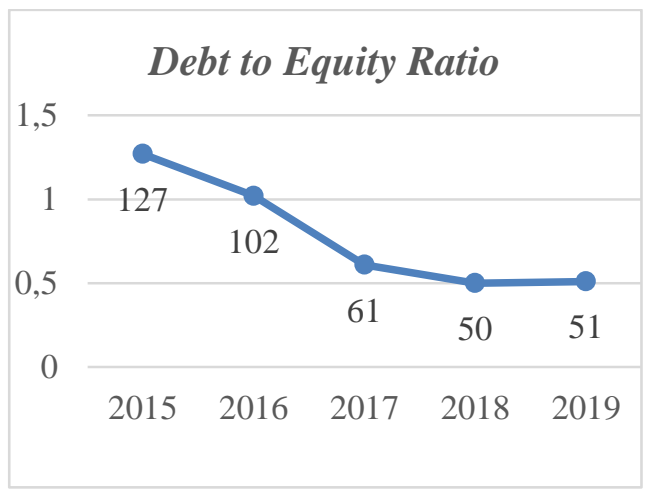

Berdasarkan grafik diatas dapat diketahui bahwa debt to equity ratio pada tahun 2015 sampai dengan tahun 2019 mengalami penurunan yang cukup signifikan dari tahun ke tahun. Hanya ditahun 2018 dan 2019 yang mengalami peningkatan sedikit. Pada tahun 2015 debt to equity ratio sebesar $127 \%$ mengalami penurunan sebesar 25\% di tahun 2016 dikarenakan terjadi penurunan utang kepada pemasok/kontraktor sehubungan dengan jasa transportasi, pembangunan pabrik baru, serta tidak adanya pembelian mesin dan peralatan. Dan mengalami peningkatan total modal dikarenakan pembelian yang dilakukan kepentingan non pengendali dan pemegang saham terhadap "Monde Nissin Corporation" oleh PT. Indomarco Prismata dan PT. Lion Superindo. Lalu, terjadi penurunan kembali pada tahun 2017 sebesar 41\% yang artinya terjadi penurunan total utang peningkatan modal dan dikarenakan terjadi penambahan total saham yang ditempatkan 
dan disetor penuh oleh Demeter Indoinvestment sebesar Rp. 941.711.531,dan Bonlight Investment mengakuisisi saham perusahaan dimana terdapat tambahan modal disetor sebesar Rp.1.285.751.685.589,-. Pada tahun 2019 terjadi peningkatan sedikit sebesar $1 \%$ dikarenakan peningkatan beban pajak atas laba sebelum pajak penghasilan per laporan laba rugi dan penghasilan komperehensif lain konsolidasian dengan menggunakan tarif pajak yang berlaku sebesar $25 \%$ dan peningkatan terhadap beban promosi yang dilakukan perusahaan selama tahun 2019. Dalam laporan keuangan laba/rugi perusahaan merupakan hal utama yang diperhatikanoleh paracalon investor untuk memastikan bahwa investasi yang dilakukanlayak dan memperoleh hasilsesuai yang diharapkan (Hamid, 2021)

\section{Dividen Payout Ratio (Kebijakan \\ Dividen) Pada PT. Nippon Indosari} Corporindo Tbk.

Kebijakan Dividen (Dividen Payout Ratio) digunakan untuk menunjukkan besaran dividen yang dibagikan terhadap total laba bersih perusahaan sekaligus mengukur besaran dividen yang dibagikan kepada pemegang saham. Semakin tinggi rasio ini maka semakin banyak laba yang dibagikan kepada para pemegang saham.
Sedangkan, semakin rendah rasio berarti laba yang tidak dibagikan digunakan perusahaan untuk mengembangkan perusahaan. berikut grafik perkembangan dividen payout ratio seperti pada gambar 3.2:

Gambar 3.2

Grafik Dividen Payout Ratio

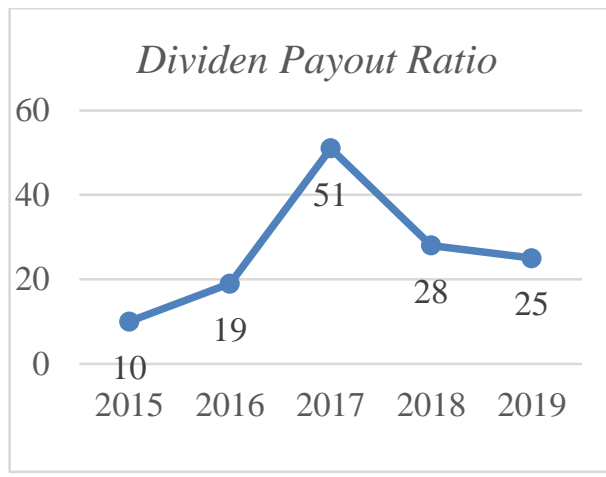

Berdasarkan grafik diatas dapat diketahui bahwa dividen payout ratio mengalami peningkatan pada tahun 2015 sampai pada tahun 2017. dividen payout ratio mengalami peningkatan yang cukup signifikan pada tahun 2017 sebesar 51\% artinya bahwa $51 \%$ laba bersih perusahaan yang memiliki kode emiten ROTI dibagikan kepada pemegang saham dalam bentuk dividen, sisanya masuk sebagai saldo laba. Peningkatan terjadi karna perseroan menganggarkan capital expendeture (capex) atau belanja modal 2017 sebesar Rp. 498 miliar, dengan rincian Rp. 398 miliar untuk belanja modal di Indonesia dan Rp. 100 miliar untuk di Filipina dengan target $20 \%$ growth revenue dari ekspansi bisnis dan produksi dan terjadi perubahan susunan pengurus 
perseroan yang disetujui oleh para pemegang saham. Namun pada tahun 2018 dan 2019 terjadi penurunan sebesar 28\% pada tahun 2018 dan 25\% pada tahun 2019 dikarenakan terjadinya penurunan laba bersih sepanjang 2018 sementara Beban Usaha tahun 2018 tercatat sebesar Rp 1,11 triliun meningkat 20,57\% dari tahun 2017. Begitupun pada tahun 2019 yang terjadi selisih penurunan sebesar 3\% dari tahun 2018 dikarenakan peningkatan yang terjadi pada beban pajak penghasilan yang meningkat dari tahun sebelumnya sebesar $85 \%$.

Namun penurunan dividen payout ratio yang terjadi masih dibilang cukup normal untuk industri yang sama dan masih wajar dari standar idustri yang telah ada.

\section{Pembobotan Nilai Perusahaan}

Adapun hasil perhitungan pembobotan nilai perusahaan PT. Nippon Indosari Corporindo Tbk melalui analisis debt to equity ratio rata-rata lima tahun terakhir sebesar 0,72 masuk katagori sangat baik berdasarkan standar rata-rata industri dan begitu juga dividen payout ratio rata-rata lima tahun terakhir sebesar $26 \%$ masuk katagori sangan baik, berdasarkan bobot tersebut maka PT. Nippon Indosari Corporindo, Tbk dapat dikatakan mempunyai nilai yang sangat baik.

\section{Pendapat Penulis}

Dalam penelitian ini penulis melakukan analisis struktur modal dan kebijakan dividen dalam mengukur nilai perusahaan, indikator yang digunakan untuk mengukur nilai perusahaan dalam penelitian ini adalah debt to equity ratio dan dividen payout ratio selama 5 tahun terakhir dari 2015-2019 PT. Nippon Indosari Corporindo Tbk.

Rata-rata hasil debt to equity ratio pada PT. Nippon Indosari Corporindo Tbk selama 5 tahun sebesar $72 \%$, apabila dilihat dari standar industri $72 \%$ berada di posisi "Sangat Baik" dan dividen payout ratio pada PT. Nippon Indosari Corporindo Tbk selama 5 tahun sebesar $26 \%$, apabila dilihat dari standar industri $26 \%$ berada di posisi "Sangat Baik".

Dari hasil ke dua indikator tersebut diatas Debt to Equity Ratio (struktur modal) dan Dividen Payout Ratio (kebijakan dividen) dapat dikatakan bahwa nilai perusahaan sangat baik di masa yang akan mendatang.

Penelitian ini membuktikan bahwa struktur modal dan kebijakan dividen dapat mengukur nilai perusahaan. Penelitian ini mendukung teori lama yaitu menurut

Harmono (2014:12), dengan adanya struktur modal yang baik dan kebijakan dividen yang dibagikan kepada para 
pemegang saham, ini dapat digunakan dalam mengukur nilai perusahaan.

\section{KESIMPULAN}

Berdasarkan hasil penelitian dan pembahasan mengenai Analisis Struktur Modal dan Kebijakan Dividen dalam Mengukur Nilai Perusahaan maka dapat disimpulkan sebagai berikut:

1. Berdasarkan hasil total struktur modal pada PT. Nippon Indosari Corporindo Tbk selama 5 tahun yaitu tahun 20152019 dengan rata-rata pertahun sebesar $78 \%$, itu artinya memiliki nilai yang sangat baik, hal ini berdasarkan standar umum rata-rata industri struktur modal yaitu $\leq 90 \%$.

2. Berdasarkan hasil total dividen payout ratio pada PT. Nippon Indosari Corporindo Tbk selama 5 tahun yaitu tahun 2015-2019, dengan rata-rata pertahun sebesar $26,6 \%$, itu artinya memiliki nilai yang sangat baik, hal ini berdasarkan standar umum rata-rata industri dividen payout ratio yaitu 25$50 \%$.

3. Hasil pengujian analisis struktur modal dan kebijakan dividen dalam mengukur nilai perusahaan Pada PT. Nippon Indosari Corporindo Tbk yang diperoleh dari laporan keuangan PT Indofood Sukses Makmur Tbk selama 5 periode dari tahun 2015-2019, berdasarkan hasil penelitian tersebut bahwa struktur modal dan kebijakan dividen dapat digunakan untuk mengukur nilai perusahaan berdasarkan nilai bobot dari masing-masing indikator dan hasilnya menunjukan nilai yang sangat bagus bagi perusahaan.

\section{REFERENSI}

Amirullah. 2015. Pengantar Manajemen. Jakarta: Mitra Wacana Media.

Baridwan, Zaki. 2020. Intermediate

Accounting. Yogyakarta:BPFE

Yogyakarta.

Franita, Riska. 2018. Mekanisme Good Corporate Governence dan Nilai Perusahaan. Medan: AGLI.

Horne, James C Van dan John M Wachowicz Jr. 2012. Prinsi-Prinsip ManajemenKeuangan (Edisi 13). Jakarta:Salemba Empat.

Harmono. 2014. Manajemen Keuangan Berbasis Balanced Scored. Jakarta: PT. Bumi Aksara 2017. Manajemen Keuangan Berbasis Balanced. Jakarta: PT. Bumi Aksara

Hikmawati, Fenti. 2017. Metodologi Penelitian. Jakarta : Rajawali Pers.

I Made Sudana. 2011. Manajemen Keuangan Perusahaan Teori dan Praktik.Jakarta:Erlangga.

Kasmir. 2015. Analisis Laporan Keuangan. Jakarta: PT. Rajagravindo Persada. 
JURNAL PARAMETER, Volume 7 No. 1, Februari 2022 Page. 57 - 68

ISSN Cetak : 1979-8865, ISSN Online : 2716-1676

Mardianto, Handono. 2010. Intisari

i2.155

Manajemen Keuangan, Jakarta: PT.

Gramedia Widiasarana Indonesia (GRASINDO).

Hamid, E. (2021). Analisis Perputaran Persediaan Dalam Menilai Return On Asset (ROA) Pada PT. Kalbe Farma, Tbk Periode 2015 - 2019. Parameter, 6(1), 1-11.

https://doi.org/10.37751/parameter.v6

i1.157

Marpaung, N. N. (2021a). Implementation of Online Learning Applications in SD Bina Kreasi Mandiri Bekasi :

Infrastructure Effect Analysis. 2019(December 2019), 1796-1807.

Marpaung, N. N. (2021b). ANALISIS

PERPUTARAN KAS DALAM

MENILAI RETURN ON ASSET

PADA PT. PRASIDHA ANEKA

NIAGA, Tbk. PARAMETER, 4(2).

https://doi.org/10.37751/parameter.v4
Marpaung, N. N. (2022). Dinamika

Kinerja Karyawan PT Adia Mirsi

Mindo ( AMM) Jakarta ; Analisis

Pengaruh Motivasi Kerja. 7(1).

Rodoni, Ali. 2014. Manajemen Keuangan

Perusahaan. Jakarta : Mitra Wacana Media.

Sugiyono. 2015. Metode Penelitian Kombinasi (Mix Methode). Bandung: Alfabeta.

Umi, Gatot Dkk. 2012.Pengaruh Kebijkan Dviden, kebijakan Hutang dan Profitabilitas terhadap Nilai Perusahaan. Jurnal JRSMI.Vol 3 No 12012

Manopo, Arie. 2016. Pengaruh Struktur Modal, Ukuran Perusahaan dan Profitabilitas Terhadap Nilai Perusahaan Otomotf. Jurnal EMBA. Vol 4 No.2. Juni 2016. https://media.neliti.com/media/publi cations/141138-ID-none.pdf. Diakses Desember Hal 485-497 